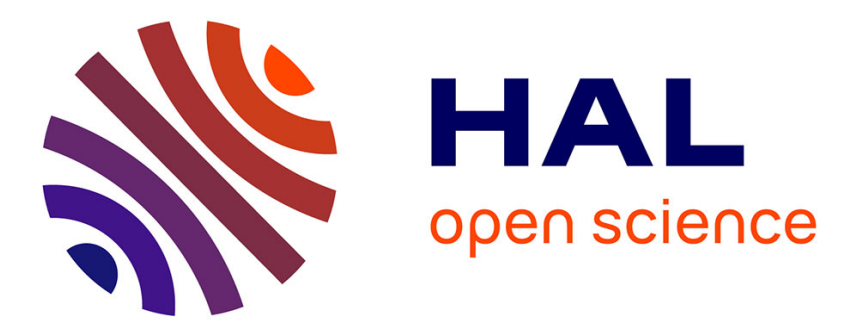

\title{
Augmented reality terahertz (AR-THz) interface for imaging and sensing
}

Jean-Paul Guillet, Frederic Fauquet, Adrien Chopard, Patrick Mounaix, Jean

Rioult, Timo Jaeschke

\section{- To cite this version:}

Jean-Paul Guillet, Frederic Fauquet, Adrien Chopard, Patrick Mounaix, Jean Rioult, et al.. Augmented reality terahertz (AR-THz) interface for imaging and sensing. IRMMW-THz 2021, 46th International Conference on Infrared, Millimeter and Terahertz Waves, Aug 2021, Chengdu, China. 1p. hal-03274777

\section{HAL Id: hal-03274777 https://hal.science/hal-03274777}

Submitted on 30 Jun 2021

HAL is a multi-disciplinary open access archive for the deposit and dissemination of scientific research documents, whether they are published or not. The documents may come from teaching and research institutions in France or abroad, or from public or private research centers.
L'archive ouverte pluridisciplinaire HAL, est destinée au dépôt et à la diffusion de documents scientifiques de niveau recherche, publiés ou non, émanant des établissements d'enseignement et de recherche français ou étrangers, des laboratoires publics ou privés. 


\title{
Augmented reality terahertz (AR-THz) interface for imaging and sensing
}

\author{
Jean-Paul Guillet ${ }^{1}$, Frederic Fauquet ${ }^{1}$, Adrien Chopard ${ }^{1}$, Patrick Mounaix ${ }^{1}$, Jean Rioult ${ }^{2}$ and Timo \\ Jaeschke $^{3}$ \\ ${ }^{1}$ University of Bordeaux, IMS Laboratory UMR CNRS 5218, 351 cours de la Libération 33405 Talence, France \\ ${ }^{2}$ Université Gustave Eiffel Laboratoire LEOST 20, rue Élisée Reclus 59666 Villeneuve d'Ascq, France \\ ${ }^{3} 2 \pi$-Labs GmbH, 44801 Bochum, Germany
}

\begin{abstract}
In order to be able to use a handled portable terahertz sensor, a solution combining augmented reality and a frequency modulated continuous wave (FMCW) radar is proposed. The achieved architecture ensures simple handling during the acquisition process while the result visualization can be performed in live directly with a smartphone, with a 3D live superimposed augmented reality view.
\end{abstract}

\section{INTRODUCTION}

$\mathrm{N}$ ON-DESTRUCTIVE testing at terahertz frequencies has benefited in recent years from advances in semiconductor technologies (Si-based and III-V-based technologies), whose frequencies have been able to move from millimetric frequencies to terahertz. There are now commercially available terahertz radars. Applications of such non-destructive testing systems are for example composite materials inspection [1] or art painting diagnosis [2]. Moreover, even if some THz handled system were demonstrated [3-4], they do not allow a direct noncontact scan and we cannot see directly the image during the acquisition.

\section{EXPERIMENTAL SETUP}

The experimental setup, illustrated on figure 1, combines an integrated wideband FMCW radar ( $122 \mathrm{GHz}$ to $170 \mathrm{GHz})$, two 3 " lenses with $115 \mathrm{~mm}$ focal length and a smartphone using a reality augmented interface. A metal place $(4 \times 8 \mathrm{~cm})$ is placed below the painting at the mouth location.

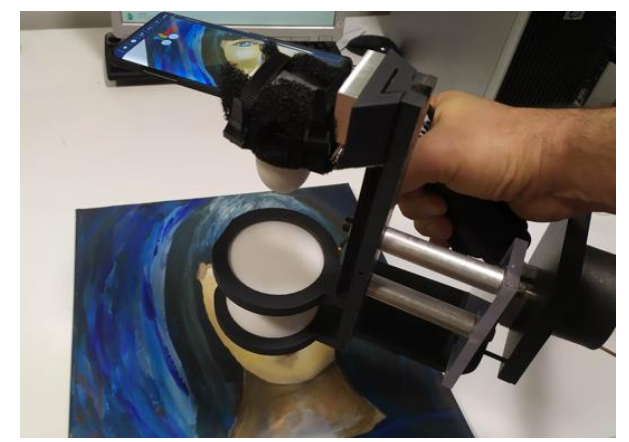

Figure 1: Photography of the experiment. A painting is manually scanned using the AR-THz system.

In this first demonstration, an intermediate processing step is performed between the radar and the smartphone in a computed. A Fourrier transform and the extraction of the amplitude corresponding to the position of the painting is sent to the smartphone as analog voltage.

\section{RESULTS}

After a first phase of calibration where we have to scan rapidly all the painting in order to generate a virtual mapping, we can move the system freely and see a THz image appearing on the phone screen with a color gradient which is superimposed on the painting (see Figure 2). It is necessary to stay in the rayleigh zone $(1 \mathrm{~cm})$ to have a homogeneous image. For this, an articulated arm allows you to move while remaining in the plane.

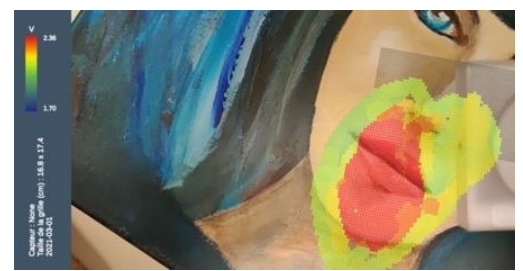

Figure 2 : Screenshoot of the mobile application with a superimposition of the camera view and the THz image.

A post measurement application allows then to see the results in augmented reality directly in the smartphone. This makes it possible to move, including with all the degrees of angular freedom, and to see the $\mathrm{THz}$ image either superimposed on the object, or by hovering a few centimeters from the object.

\section{SUMMARY}

The feasibility of AR-THz using FMCW imaging system is proven. A good match between the spatial resolution of the manual scan assisted by a telephone and the resolution of the radar makes it possible to quickly obtain information on the analyzed object, with the possibility of seeing it in augmented reality. Radar signal processing in the computer is still a limitation at this time, but it could be integrated in the smartphone in the future.

\section{REFERENCES}

[1]. Pan, M., Chopard, A., Fauquet, F., Mounaix, P., \& Guillet, J. P. (2020). Guided Reflectometry Imaging Unit Using Millimeter Wave FMCW Radars. IEEE Transactions on Terahertz Science and Technology, 10(6), 647655.

[2]. Guillet, J. P., Wang, K., Roux, M., Fauquet, F., Darracq, F., \& Mounaix, P. (2016, September). Frequency modulated continuous wave terahertz imaging for art restoration. In 2016 41st International Conference on Infrared, Millimeter, and Terahertz Waves (IRMMW-THz) (pp. 1-1). IEEE.

[3]. Duling III, I. N. (2016, May). Handheld THz security imaging. In Image Sensing Technologies: Materials, Devices, Systems, and Applications III (Vol. 9854, p. 98540N). International Society for Optics and Photonics.

[4]. Ellrich, F., Bauer, M., Schreiner, N., Keil, A., Pfeiffer, T., Klier, J., ... \& Molter, D. (2020). Terahertz quality inspection for automotive and aviation industries. Journal of Infrared, Millimeter, and Terahertz Waves, 41(4), 470489. 